\title{
Musik Keroncong Campur Sari dalam Pluralitas Budaya Masyarakat Sawahlunto
}

\author{
Yon Hendry \\ Jurusan Musik, Fakultas Seni Pertunjukan, Institut Seni Indonesia Padang Panjang
}

\begin{abstract}
ABSTRAK
Artikel ini membahas fenomena musik keroncong campur sari yang berkembang di daerah Sawahlunto. Untuk memahami fenomena ini digunakan studi kasus pada Orkes Keroncong Campur Sari Irama Masa Sawahlunto. Berdasarkan penelitian disimpulkan bahwa musik Keroncong Campur Sari yang hidup di dalam masyarakat Sawahlunto sangat berbeda dengan yang hidup di Jawa. Alat musik yang digunakan mengakomodasi alat musik dari berbagai etnis yang hampir mewakili semua etnis masyarakat yang hidup di Sawahlunto. Kondisi demikian pula yang menjadi alasan bahwa kesenian tersebut tidak bernama Campur Sari seperti di Jawa. Meskipun masih menggunakan istilah campur sari, tetapi pola permainan musiknya dan repertoar lagunya pun merupakan percampuran dari berbagai tradisi masyarakat yang hidup di dalamnya. Dengan demikian jelas bahwa pluralisme masyarakat Sawahlunto di sini terrefleksikan pada pluralisme alat musik dan permainan orkesnya.
\end{abstract}

Kata kunci: keroncong, campursari, musik tradisi.

\begin{abstract}
Keroncong Campur Sari Music in Pluralism Sawablunto People. This article mainly discusses about the keroncong music phenomenon, campur sari, that has been developed well in Sawahlunto. In order to understand this phenomenon, a case study was used for the research in campur sari keroncong orchestra "Irama Masa" Sawahlunto. Based on the research, it can be concluded that there is a significant difference between the keroncong music campur sari in Sawahlunto and in Java. The music instruments used for campur sari are those which accommodate some music instruments from the ethnic groups live in Sawahlunto. Based on this characteristic, therefore, the name of this keroncong music is not similar to the music that is well known in Java, Campur Sari. Although the name of campur sari is still being used, but basically, the pattern in performing the music and its repertory are based on the mixing of many cultural aspects of people living there. Therefore, the pluralism of people in Sawablunto is reflected clearly on the pluralism of music instruments and of the orchestra performance.
\end{abstract}

Keyword: keroncong, campur sari, traditional music.

\section{Pendahuluan}

Behaque berpendapat bahwa seni pertunjukan merupakan istilah yang sangat luas dan memiliki berbagai perspektif. Seni pertunjukan yang dimaksud di sini adalah cultural performance (pertunjukan budaya) yang kontekstual (Bangun, 1994: 88). Musik Keroncong Campur Sari yang berkembang di Sawahlunto, sebagai sebuah seni pertunjukan adalah ensambel musik yang dimiliki oleh masyarakatnya yang majemuk, multi etnik. Masyarakat Sawahlunto yang majemuk telah melahirkan suatu genre musik baru yang kemudian mereka sebut dengan Musik Keroncong Campur Sari. Namun konsep campur sari yang digunakan berbeda dengan istilah campur sari yang berkembang di daerah Jawa dewasa ini, yakni suatu kelompok musik yang memadukan alat musik keroncong dengan gamelan Jawa, dan lebih dominan membawakan lagu-lagu keroncong dan lagu Jawa. Akan tetapi, Musik Keroncong Campur Sari yang ada di Sawahlunto memadukan alatalat musik keroncong dengan alat musik Barat (biola, gitar elektrik, gitar bas elektrik, keyboard, drum, tamburin); alat musik Jawa (saron); alat musik Melayu (gendang melayu); dan alat musik Minang (talempong). Sedangkan lagu-lagu yang dibawakan adalah lagu-lagu keroncong, lagu-lagu yang berasal dari daerah Jawa, Minangkabau, Batak, Bugis, Nias, Melayu, dan sebagainya. Bahkan lagu-lagu gamat (Melayu), lagu Minang, lagu Jawa, dan lagu Batak selalu menjadi materi utama dari pertunjukannya. Selain itu, para pemain dari kelompok Musik Keroncong Campur Sari ini, juga didukung oleh berbagai etnis.

Meskipun demikian, sajian yang dibawakan oleh kelompok Musik Keroncong Campur

1 Alamat korespondensi: Jurusan Musik, ISI Padang Panjang. Jalan Bunda Kanduang No. 35 Padang Panjang- 27128. HP: 0812676 8409. E-mail: yon.hendry@gmail.com 
Sari dapat berpadu menjadi satu kesatuan yang mempunyai karakteristik tersendiri. Oleh karena itu keberadaannya dapat dipandang sebagai musik etnis tersentiri. Sebagai sebuah pertunjukan budaya (seni), tampilan Musik Keroncong Campur Sari memiliki nilai estetis yang dapat dikaji melalui sudut pandang subyektif dan obyektif. Sudut pandang subyektif terpusat pada sisi diri orang yang melihat atau menikmatinya, sedangkan sisi obyektif menempatkan pada barang yang dilihat (Soedarso, 1990: 36).

Perpaduan berbagai unsur budaya serta perpaduan berbagai jenis alat instrument, jelas menunjukkan bahwa Musik Keroncong Campur Sari ini merupakan jenis musik yang sangat unik untuk dipersembahkan dalam sebuah pertunjukan. Pertunjukannya sangat menarik perhatian penonton, sehingga kelompok-kelompok musik ini sering dipesan untuk acara-acara sosial kemasyarakatan, dan akhirnya menjadi tradisi bagi masyarakat setempat. Yang menjadi pertanyaan adalah: "Apa yang melatarbelakangi lahirnya Musik Keroncong Campur Sari di tengah masyarakatnya yang majemuk, dan kenapa genre baru ini hanya lahir di Sawahlunto dan tidak terdapat di daerah lain?”

Pertanyaan tersebut sangat erat kaitannya dengan latar belakang daerah itu sendiri, sebagai masyarakat yang berlatar belakang multietnis, tetapi Musik Keroncong Campur Sari yang berasal dari satu etnis (Jawa) mampu mempersatukan masyarakat yang multietnis tersebut. Yang menjadi pertanyaan berikutnya adalah "Bagaimana pemahaman masyarakat pendukung terhadap Musik Keroncong Campur Sari?"

Bentuk kajian dalam seni pertunjukan Musik Keroncong Campur Sari tersebut dapat dipahami dengan mempergunakan dua konsep yaitu dari segi musikalisasi dan instrumentasinya. Sedangkan harmonisasi yang terjadi pada sajian Musik Keroncong Campur Sari dapat terjadi dari perpaduan beberapa instrumen yang saling mengisi dalam penyajian sebuah lagu dan juga antara instrumen pendukung dengan penyanyi. Perpaduan dan kesatuan tersebut akan menimbulkan suatu makna estetis dari sebuah pertunjukan. Melalui instrumentasi yang mendukung pertunjukan Musik Keroncong Campur Sari lebih banyak memberikan pandangan kepada penonton tentang makna dari sebuah pertunjukan Musik Keroncong Campur Sari.

Sebelum membahas tentang hal-hal yang mendukung pertunjukan Musik Keroncong Campur Sari akan diuraikan dulu sejarah munculnya Musik Keroncong Campur Sari di Kota Sawahlunto dan membandingkannya dengan sejarah Musik Campur Sari di Jawa.

\section{Campur Sari Jawa}

Sebelum membahas Musik Keroncong Campur Sari yang ada di Sawahlunto, perlu ditinjau pula awal mula keberadaan Musik Campur Sari di Jawa sebagai daerah asal. Apabila kita coba melihat sejarah seni pertunjukan Jawa, maka di beberapa tulisan disebutkan bahwa genre Campur Sari baru muncul pada panca warsa terakhir. Dilihat dari ensambelnya, Campur Sari tergolong ensambel baru dalam blantika musik Indonesia, yakni merupakan akulturasi dari ensambel keroncong dan karawitan Jawa. Kontak antara keroncong dan karawitan Jawa tersebut, awalnya intensif terjadi di RRI (Radio Republik Indonesia). Setiap stasiun RRI di Jawa selalu mempunyai grup karawitan dan grup orkes keroncong, sehingga hal ini memungkinkan terjadinya kontak intensif antara gamelan dan musik lainnya, terutama musik keroncong (Laksono, 2010: 5).

Penggabungan karawitan Jawa dengan musik keroncong ini, awalnya terjadi pada tahun 1960-an, sedangkan instrumen yang digabung adalah kendang, siter, dan gender (dari ensambel karawitan Jawa) digabung dengan bas, cuk, gitar, dan biola (dari ensambel keroncong) (Laksono, 2010: 5). Melihat penggabungan dua jenis musik tersebut terjadi setelah kemerdekaan Indonesia, maka hal ini selaras dengan pendapat Judith Becker (1980: 38), bahwa setelah kemerdekaan ada kecenderungan para seniman (terutama seniman karawitan) dalam membuat lagu mencampur unsur-unsur aransemen musik. Apabila pada zaman sebelum kemerdekaan orientasinya hanya kedaerahan, maka setelah kemerdekaan orientasinya nasional.

Terbentuknya genre musik Campur Sari di daerah Jawa mempunyai sejarah yang cukup unik, sebab berawal dari sebuah warung bakmi yang bernama Warung Bakmi Lestari. Warung ini sangat ramai dikunjungi pelanggan. Untuk menarik para pelanggan tersebut, pemilik warung 
menyediakan hiburan siteran climen, yaitu alat musik Jawa yang dimainkan dengan teknik dipetik. Di antara pelanggan warung bakmi ini adalah tiga orang pemain musik keroncong yang menamakan diri mereka Manthou's, yang anggotanya terdiri dari Suhardjono, Yunianto, dan Heru (Laksono, 2010: 6).

Suatu ketika setelah melakukan latihan keroncong, Manthou's datang ke warung bakmi tersebut, secara iseng mereka bergabung dengan siteran climen. Hasil dari musik tersebut dirasakan enak oleh para pelanggan yang hadir saat itu, di antaranya adalah Sutrisna (pemilik PO Maju Lancar). Sutrisna mendukung sekali keberadaan musik tersebut dan beberapa waktu kemudian membelikan peralatan yang dibutuhkan untuk jenis musik yang baru ini, termasuk keyboard (Laksono, 2010: 6).

Keberadaan genre ini amat menarik bagi masyarakat setempat, yaitu masyarakat di daerah Gunung Kidul, mereka menyebutnya dengan Campur Sari. Kelompok Campur Sari ini kemudian dibiayai oleh Sutrisna sebagai pemilik PO Maju Lancar hingga ke dapur rekaman. Sehingga lahirlah kelompok Campur Sari pertama di daerah Jawa yang bernama Campur Sari Gunung Kidul Maju Lancar (CSGK Maju Lancar) (Laksono, 2010: 6).

Para penyanyi dari CSGK Maju Lancar berangkat dari penyanyi keroncong dan pesinden, yaitu penyanyi wanita pada kelompok seni gamelan atau pertunjukan wayang (golek, kulit) (Ali, 1994: 762). Langkah penggabungan kedua jenis musik di atas ditiru oleh kelompok Orkes Bintang Jakarta, karena salah seorang anggota dari kelompok orkes ini sampai awal tahun 1970an adalah Manthou's, yaitu Ketua CSGK Maju Lancar (Laksono, 2010).

Awal mula keberadaan genre Campur Sari ini tertuang dalam lagu Campur Manis I, sedangkan arti Campur Sari sendiri menurut Manthou's tertuang dalam lagu Campur Manis II, di antaranya bersyair:

\section{... Campur Sari iku kalebu budhaya \\ Kang rinipta lan uga karengga \\ Pambukane lumantar buka swara \\ Sumadya anglipur kinarya gumbira}

\section{Bidhuan sarta pasindhenne}

Bas, viol, gong, siter, pangendhange
Ririh rampak dhemes pamithete

Weh rena kang miyarsakke..... (Laksono, 2010: 8).

Hal lain yang kemudian dapat disimak adalah bahwa secara langsung maupun tidak langsung, jumlah grup Campur Sari semakin lama justru semakin bertambah. Khusus di Yogyakarta, terdapat 48 grup Campur Sari yang layak jual (Laksono, 2010: 4). Selain jumlah grup yang nampak terus berkembang, Campur Sari difungsikan dalam berbagai kegiatan di masyarakat, yang menandakan bahwa semakin kuatnya keberadaan Campur Sari tersebut.

\section{Campur Sari Sawahlunto}

Munculnya genre musik Campur Sari di daerah Jawa, menimbulkan ide bagi Bapak Adjoem dan kawan-kawan untuk menciptakan jenis musik Campur Sari sebagai sebuah genre baru di Sawahlunto. Musik campur sari di Sawahlunto, merupakan suatu bentuk seni pertunjukan yang lahir di daerah Sawahlunto Sumatera Barat. Bentuk dan strukturnya tidak sama dengan musik campur sari yang lahir di daerah Jawa. Keberadaan jenis musik ini berawal dari hadirnya musik keroncong di tengah-tengah masyarakat Sawahlunto.

Kehadiran musik keroncong di daerah Sawahlunto, berawal dari kesibukan para pekerja di Tambang Batubara Ombilin. Untuk menghilangkan kejenuhan sehari-hari mereka mendengarkan radio dalam menghabiskan waktu istirahatnya. Suatu ketika terdengar beberapa buah lagu keroncong yang disiarkan oleh sebuah radio. Tanpa disengaja, lagu-lagu keroncong tersebut langsung ditanggapi oleh beberapa pekerja yang pada umumnya berasal dari daerah Jawa. Sejak saat itu untuk menghilangkan kejenuhan dalam bekerja seharian, musik keroncong dijadikan sebagai hiburan pelepas lelah oleh para pekerja tambang. Namun ketika pemerintah Hindia Belanda mendengarkan jenis seni pertunjukan ini, mereka tertarik dan langsung pula menanggapi, sehingga fungsi musik keroncong menjadi lebih luas, terutama sekali dalam menghibur pemerintah kolonial Hindia Belanda. Pada masa berikutnya, mulai terbentuk sebuah kelompok musik keroncong yang anggotanya terdiri dari pekerja Tambang Batubara Ombilin tersebut. Peristiwa ini terjadi 
sekitar tahun 1937. Alat musik yang dipergunakan dalam pertunjukannya masih sangat terbatas, di antaranya adalah gitar, kontra bas, drum, dan tifa. Namun pada tahun 1938 alat musik yang mereka mainkan bertambah dengan beberapa alat musik lainnya seperti keyboard, klarinet, dan saksofon (Dedi Iswandi, 2003).

Selanjutnya, kelompok musik keroncong ini telah mulai menggunakan alat-alat musik seperti; cuk, ukulele, gitar, biola, cello, kontra bas, dan tenor saksofon. Keberadaan musik keroncong tersebut mulai diakui masyarakat, sehingga pada tahun 1946 di bawah pimpinan Bapak Tarmin, seorang pemain biola dan merupakan seniman musik keroncong yang sangat mahir di Sawahlunto saat itu. Beliau berasal dari keturunan Jawa dan sehari-hari bekerja sebagai penambang batubara. Mereka melahirkan kelompok Orkes PETA (Orkes Musik Keroncong Pemuda Tanah Lapang), yang bertahan hingga tahun 1959. Karena para pemain Orkes PETA banyak yang pindah untuk berdomisili ke daerah lain, maka pada tahun 1961 kelompok ini pecah. Namun seiring dengan perkembangan kota Sawahlunto saat itu, muncul sejumlah kelompok-kelompok musik keroncong baru, antara lain kelompok musik keroncong $P R$ di kota Sawahlunto, kelompok musik keroncong Bunga Kenari di Sawahlunto, kelompok musik keroncong Istana Muda di Durian Sawahlunto, dan kelompok musik keroncong Perwira di Sawahlunto.

Pada tahun 1965, seiring dengan terjadinya gerakan 30 September yang dikenal dengan gerakan G-30 S, maka kelompok-kelompok musik keroncong ini banyak yang bubar. Satu-satunya kelompok musik keroncong yang tertinggal di Sawahlunto waktu itu adalah kelompok musik keroncong Perwira. Kelompok ini dipimpin oleh seorang perwira TNI yang bernama Kapten Shopa. Orkes keroncong ini sangat terkenal di Sawahlunto Barat, dan pernah mengadakan pertunjukan di sekitar Sawahlunto sendiri serta beberapa kota lain seperti Padang, Bukittinggi, dan Solok. Namun, kelompok musik keroncong Perwira ini pun hanya bertahan hingga tahun 1976. Selanjutnya pada tahun 1977 , Anita sebagai salah seorang penyanyi wanita yang terkenal di daerah Sawahlunto pada saat itu mengumpulkan kembali-penyanyi-penyanyi yang masih tersisa dari kelompok-kelompok musik keroncong di Sawahlunto. Anita ini kembali mendirikan sebuah kelompok musik keroncong baru yang bernama Orkes PETA (Orkes Keroncong Pemuda Tambang Arang.) Karena hubungan komunikasi kelompok ini sangat baik dengan pihak RRI Padang, maka pihak RRI Padang melengkapi instrumen kelompok ini dengan alat-alat musik seperti pikolo, seruling, cello dan gitar melodi. Para pemain yang ada pada kelompok musik keroncong ini dilatih untuk lebih mendalami alat musik keroncong mereka masing-masing secara lebih baik. Sedangkan untuk penyanyi keroncong juga dilakukan latihan tambahan agar dapat menyanyikan lagu-lagu keroncong dengan lebih baik dan sempurna. Tetapi sebelum terujud sepenuhnya tujuan dari Orkes PETA ini, pada tahun 1980 dr. Anita pindah tugas ke daerah Jawa. Maka pada tahun 1980-1985, kelompok musik PETA langsung dipimpin oleh kepala Tambang Batubara Ombilin. Penampilan kelompok musik ini dilakukan setiap bulannya sebagai suatu bentuk hiburan bagi keluarga dan karyawan Tambang Batubara Ombilin waktu itu.

Pada tahun 1986-1998, orkes keroncong PETA yang dipimpin oleh kepala Tambang Batubara Ombilin tersebut, mengalami perubahan sehingga menjadi sebuah kelompok Band, yang bernama Taroria. Selain memainkan lagu-lagu keroncong kelompok kesenian ini juga memainkan lagu-lagu pop Indonesia, Barat, dan lagu-lagu Minang. Di tahun 1999, melalui prakarsa seorang pemain keroncong dari daerah luar Sawahlunto, maka dihidupkan kembali sebuah kelompok musik keroncong murni atau kelompok keroncong yang sesungguhnya. Kelompok ini diberi nama Paguyuban. Hingga saat ini kelompok musik keroncong tersebut sangat fungsional di masyarakat, pertunjukannya dianggap sebagai sebuah tradisi yang harus selalu melekat dengan berbagai macam peristiwa adat, maupun pestapesta rakyat atau perayaan yang diadakan oleh masyarakat.

Di awal-awal tahun berdirinya orkes keroncong Paguyuban ini berjalan dengan baik, akan tetapi banyak sekali permasalahan yang dihadapi oleh para pendukungnya, di antaranya: (1) karena alatalat musik yang dipergunakan sudah tua, sehingga hasil penampilan dari kelompok ini pun kurang kualitasnya; (2) para pemain musik keroncong yang diharapkan juga sudah banyak yang tua dan 
meninggal; dan (3) tidak adanya usaha untuk mewariskan seni pertunjukan ini kepada generasi muda. Banyaknya persoalan yang dihadapi menyebabkan kegiatan kelompok ini menjadi mundur kembali. Karena perkembangan zaman yang semakin maju, menyebabkan penampilan kelompok musik keroncong ini semakin kurang diminati oleh masyarakat. Apalagi bentuk musik yang ditampilkan memiliki nuansa yang lambat, yang berbeda sekali dengan jenis-jenis musik yang mulai berkembang di tengah masyarakat saat itu, seperti organ tunggal yang membawakan lagu-lagu yang lebih energik seperti lagu dangdut, pop, rock, dan sebagainya. Perkembangan zaman tersebut menyebabkan kaum muda Sawahlunto sempat memberi nama orkes keroncong ini dengan "orkes ngantuk".

Kondisi pertunjukan musik keroncong yang sudah semakin "lesu" di Sawahlunto pada tahun 1990-an, ternyata menimbulkan inspirasi baru bagi seniman lainnya. Maka pada tahun 1994, salah seorang seniman (musik keroncong) Bapak Adjoem yang sehari-harinya aktif sebagai pekerja tambang, mempelopori sebuah kelompok musik jenis baru yang diberi nama Kelompok Musik Campur Sari. Dalam hal ini Bapak Adjoem berusaha menarik kembali para peminat musik keroncong baik dari pihak generasi tua maupun generasi muda. Selain itu, kemunculan jenis musik campur sari ini adalah untuk menghilangkan image masyarakat yang selama ini menganggap bahwa musik keroncong adalah musik yang ngantuk dan hanya untuk kalangan tua saja.

Campur sari yang lahir di daerah Sawahlunto ini tentu saja berbeda dengan musik campur sari yang lahir di daerah Jawa. Sebab dalam pertunjukannya, musik campur sari Jawa khusus menggunakan bahasa Jawa dalam mengalunkan lagu-lagu keroncong dan lagu daerah Jawa. Sedangkan dalam musik campur sari Sawablunto, gaya (style) musik keroncong diramu dengan berbagai jenis musik lainnya berirama pop, dangdut, reggae, rock, salsa di dalam sebuah pertunjukan. Bagian-bagian lain yang diramu adalah lagu-lagu yang dimainkan, dapat berupa lagu-lagu dari bermacam daerah seperti Minangkabau, Batak, Bugis, Melayu, Sunda, Jawa, dan sebagainya; sedangkan bahasa yang dipergunakan tetap bahasa daerah dari masing-masing lagu yang dimainkan; alat musik yang dipergunakan pun bermacam-macam, tidak terbatas kepada alat musik keroncong saja seperti biola, flute, cak, cuk, gitar, cello, dan kontra bass, akan tetapi telah ditambah dengan berbagai alat musik lainnya, yang kadangkala disesuaikan dengan berbagai alat instrumen yang dibutuhkan dari jenis lagu-lagu daerah atau lagu pop, seperti gitar bass elektrik sebagai pengganti Kontra bass dan cello, juga adanya alat perkusi yaitu drum serta keyboard yang menjadi pendukung serta penyeimbang estetis bunyi kesemua alat. Semuanya dimodifikasi dan diramu sedemikian rupa sehingga menjadi sebuah pertunjukan campur sari yang sangat kompleks untuk dinikmati.

Dengan demikian musik campur sari yang dimunculkan oleh Bapak Adjoem sangat berbeda dengan musik campur sari yang berasal dari daerah Jawa. Baik dari segi alat musik yang dipergunakan, lagu-lagu yang dimainkan, pemain, maupun penonton yang menikmatinya. Nuansa musik campur sari yang ditimbulkan semenjak tahun 1994 tersebut membawa hasil yang gemilang. Seluruh lapisan masyarakat Sawahlunto sangat antusias dan senang mendengarkan musik tersebut, baik dari kalangan generasi tua ataupun dari kalangan generasi muda. Kegiatan tersebut berlangsung hingga saat ini.

Bapak Adjoem sebagai pelopor dan temanteman pendukung yang mencintai musik keroncong sekaligus sebagai pemain musik keroncong selama ini, melakukan berbagai upaya untuk kepentingan musik campur sari. Mereka mencari kiat-kiat untuk kembali menarik penikmat musik keroncong selama ini, terutama dari golongan generasi muda. Kelompok campur sari ini kemudian mereka beri nama Orkes Keroncong Campur Sari Irama Masa Sawablunto.

\section{Pluralitas Alat Musik Orkes Keroncong Campur Sari Irama Masa}

Sebelum melihat teknik permainan dari alat musik Orkes Keroncong Campur Sari Irama Masa, perlu diterangkan dulu beberapa macam alat musik yang dipergunakan dalam setiap pertunjukan mereka akhir-akhir ini. Terutama sekali dalam pertunjukan Orkes Keroncong Campur Sari Irama Masa di Pentas Pedati V Bukittinggi. Dari beberapa buah lagu yang ditampilkan, diambil kasus tiga buah lagu yaitu 
Sawahlunto Kota Idaman, Medley Otano Batak \& Minangkabau, dan Bagus Ade.

Lagu Sawahlunto Kota Idaman dibawakan oleh beberapa orang penyanyi dan didukung oleh alat musik yang terdiri dari: Cuk, Gitar melodi elektrik, Gitar bas elektrik, Saron I, Saron II, Drum (set), Gendang Bermuka Dua (gendang Jawa), dan Keyboard. Lagu Medley Otano Batak \& Minangkabau dibawakan oleh beberapa orang penyanyi dan didukung oleh alat musik yang terdiri dari Seruling Batak. Cuk, Gitar melodi elektrik, Gitar bas elektrik, Saron I, Saron II, Drum (set), Gendang Bermuka Dua, dan Keyboard. Lagu Bagus Ade, adalah salah satu lagu yang berasal dari Jawa Barat dibawakan oleh seorang penyanyi dan didukung oleh alat musik yang terdiri dari Cuk, Gitar melodi elektrik, Gitar bas elektrik, Saron I, Saron II, Drum (set), Gendang Bermuka Dua. Dan Keyboard.

Ketiga buah lagu yang dijadikan studi kasus tersebut semua didukung oleh alat musik Seruling Batak, Cuk, Gitar Melodi Elektrik, Gitar Bas Elektrik, Saron I, Saron II, Drum (set), Gendang Bermuka Dua, dan Keyboard.

\section{Seruling Batak}

Seruling Batak dalam Orkes Keroncong Campur Sari Irama Masa berfungsi sebagai pembawa melodi intro dalam lagu-lagu Batak yang dimainkan oleh kelompok ini. Selain itu alat musik ini juga berfungsi memainkan melodi vokal. Dalam membawakan melodi intro, Seruling Batak memperlihatkan ciri khas gaya (style) melodi daerah Batak, sehingga setiap pendengar akan tahu kalau yang dimainkan adalah seruling Batak. Teknik main Seruling Batak pada intro terdapat pada lagu:

\section{Cuk}

Alat ini termasuk instrumen tali petik, dan berfungsi sebagai pemegang ritmis. Cuk yang dipergunakan dalam Orkes Keroncong Campur Sari Irama Masa mempunyai snar tiga buah yang terbuat dari bahan nilon. Stem nada ketiga buah snar adalah g" - b' - e". menurut Harmunah alat musik Cuk jenis ini disebut ukulele stem $\mathrm{E}$ (Harmunah, tanpa tahun: 26).

Teknik memainkan alat musik ini adalah dengan cara dipetik secara arpegio (Kodiyat, 1986:
5), yaitu teknik permainan nada-nada dengan cepat secara berurutan seperti petikan pada alat musik harpa. Kadang-kadang teknik arpegio ini divariasikan dengan menambah variasi dengan jarak seconde dari nada terakhir sebuah arpegio. Teknik seperti ini terdapat dalam lagu Sawahlunto Kota Idaman birama 5/1 - 55/4 dan birama 62/1 - 87/1 dan Medley Otano Batak \& Minangkabau birama 24/1 - 28/4 dan birama 53/1 - 54/1.

Teknik arpegio yang divariasikan dengan jarak seconde dari nada terakhir sebuah arpegio terdapat pada lagu Medley Otano Batak \& Minangkabau birama 24/1 - 28/4. Teknik arpegio yang divariasikan dengan jarak seconde dari nada terakhir sebuah arpegio terdapat pada lagu Medley Otano Batak \& Minangkabau birama 53/1 - 54/1. Selain teknik memainkan nada secara berurutan tersebut, arpegio juga divariasikan dengan menggunakan harga nada $1 / 32$ untuk pembawaan ritme yang rangkap. Teknik ini terdapat dalam lagu Sawahlunto Kota Idaman birama 56/1 - 62/1, Medley Otano Batak \& Minangkabau birama 29/1 - 51/4, Bagus Ade birama 30/1 - 44/4.

Teknik arpegio dapat divariasikan dengan menggunakan harga nada 1/32 untuk pembawaan ritme yang rangkap. Ini terdapat pada lagu Sawahlunto Kota Idaman birama 56/1 - 62/1. Teknik arpegio juga dapat divariasikan dengan menggunakan harga nada $1 / 32$ untuk pembawaan ritme yang rangkap misalnya pada lagu Medley Otano Batak \& Minangkabau birama 29/1 51/4. Teknik arpegio dapat divariasikan dengan menggunakan harga nada 1/32 untuk pembawaan ritme yang rangkap terdapat pada lagu Bagus Ade birama 30/1 - 44/4.

Selain kedua teknik di atas, Cuk juga dimainkan dengan teknik akor (It: accordo), yaitu beberapa buah nada yang dimainkan secara serempak (Kodiyat, 1986: 2), namun mengikuti ritme-ritme lagu dengan teknik ritmis. Teknik ini dipergunakan pada lagu Medley Otano Batak \& Minangkabau birama 6/1 - 21/4, Bagus Ade birama 2/1 - 24/4 atau pada birama 46/1 - 52/4. Cuk yang dimainkan dengan teknik akor yaitu beberapa buah nada yang dibunyikan serempak (lagu Medley Otano Batak \& Minangkabau birama $6 / 1-21 / 4)$. Cuk yang dimainkan dengan teknik akor yaitu beberapa buah nada yang dibunyikan serempak (Bagus Ade birama 46/1 - 52/4). 
Teknik terakhir di atas menurut istilah dalam teknik permainan gitar disebut "rasgueado" (Spanyol), dengan alat plecktrum. Pada tahun 1958 dikembangkan dengan cara permainannya oleh Bapak Abdulrazak, seorang pemain keroncong dari Orkes Studio Surakarta. Dari permainan rasgueado menjadi petikan repetisi pada satu snar berdasarkan akor yang dibawakan. Rasgueado dimainkan pada pukulan tertentu yaitu pukulan pertama dan ketiga. Iramanya tenang dan ajeg, dengan kebebasan perkembangan akor sedikit (Harmunah, tanpa tahun: 26).

\section{Gitar Melodi Elektrik}

Alat ini termasuk instrumen petik (keluarga instrumen tali), jadi agak berbeda dengan biola yang termasuk instrumen gesek. Alat musik ini dalam Orkes Keroncong Campur Sari Irama Masa berfungsi mengikuti tangganada dan lompatan sedikit naik atau turun, artinya lebih kurang diatonic, dan merupakan uraian dari akor yang sedang dibawakan dengan harga nada $1 / 8$ atau $1 / 6$ untuk ritmenya, dan mempergunakan harga nada $1 / 32$ untuk pembawaan ritme yang rangkap. Jangkauan nadanya tidak hanya pada suara tengah saja, tetapi bergerak ke atas maupun ke bawah. Teknik ini ditemukan pada lagu Medley Otano Batak \& Minangkabau birama 38/1 - 53/4

Pada permainan dengan nada $1 / 8$, sering terjadi permainan singkop atau triol. Hal ini terdapat dalam lagu Bagus Ade birama 20/1 21/4. Ini sama dengan birama 23/3 - 24/4. Permainan singkop atau triol gitar melodi elektrik (lagu Bagus Ade birama 20/1 - 21/4 juga terdapat juga pada birama dan 23/3 - 24/4). Permainan dengan nada $1 / 4$, sering juga ditemukan di dalam aransemen Orkes Keroncong Campur Sari Irama Masa, misalnya terdapat dalam lagu Sawahlunto Kota Idaman birama 10/1 - 28/4 dan birama 46/1 - 83/1 dan Medley Otano Batak \& Minangkabau birama 22/2 - 37/4.

Permainan dengan nada $1 / 4$ yang sering juga ditemukan di dalam aransemen Orkes Keroncong Campur Sari Irama Masa (Sawahlunto Kota Idaman birama 46/1 - 83/1. Permainan dengan nada $1 / 4$ yang sering juga ditemukan di dalam aransemen Orkes Keroncong Campur Sari Irama Masa (Sawahlunto Kota Idaman birama 10/1 28/4). Permainan dengan nada $1 / 4$ yang sering juga ditemukan di dalam aransemen Orkes Keroncong Campur Sari Irama Masa (lagu Medley Otano Batak \& Minangkabau birama 22/2 - 37/4).

Selain teknik di atas, alat musik gitar dalam aransemen Orkes Keroncong Campur Sari Irama Masa juga berfungsi sebagai pembawa melodi intro, interlude, coda, serta filler atau potongan melodi yang mengisi istirahat, terutama pada peralihan akor tonika ke sub dominan, atau ke dominan. Sebagai pembawa melodi intro terdapat pada lagu Sawahlunto Kota Idaman birama 1/24/1, Bagus Ade birama 1/2 - 9/2.

Alat musik gitar dalam fungsinya sebagai interlude, terdapat pada lagu Sawahlunto Kota Idaman birama 29/2 - 44/4 dan Bagus Ade birama $45 / 1$ - 53/2. Alat musik gitar dalam fungsinya sebagai coda, terdapat pada lagu Sawahlunto Kota Idaman birama 83/2 - 86/2. Alat musik gitar dalam fungsinya sebagai pembawa filler, terdapat pada lagu Bagus Ade birama 12/2 - 13/2, birama $18 / 2-19 / 2$, birama $22 / 2-23 / 2$ ' birama $28 / 2$ 29/2; dan birama 36/2 - 37/2.

\section{Gitar Bas Elektrik}

Orkes Keroncong Campur Sari Irama Masa juga mempergunakan alat musikbasatau contrabas serta cello. Namun dalam suatu pertunjukan mereka di Pentas Pedati V Bukittinggi tidak dipergunakan bas atau contrabas serta cello. Hal ini disebabkan karena pentas pertunjukan cukup jauh dari lokasi pemukiman kelompok Orkes Keroncong Campur Sari Irama Masa, yaitu di Desa/Kelurahan Durian II Kota Sawahlunto.

Sebagai pengganti dari bas atau contra bas serta cello ini dipergunakan gitar bas elektrik. Penggunaan alat musik gitar bas elektrik ini tidak mengurangi estetika dari pertunjukan, karena peranan dari contrabas dan cello di bawakan oleh gitar bas elektrik. Gitar bas elektrik yang dipergunakan dalam pertunjukan ini berfungsi sebagai pengendali ritmis. Bertali empat dengan stem nada $\mathrm{E}-\mathrm{A}-\mathrm{D}-\mathrm{G}$.

Alat ini memainkan nada bawah (low) dari akor yang sedang dibawakan. Ketepatan ritme dari setiap petikan sangat dibutuhkan, atau dengan kata lain, attack harus tepat. Gitar elektrik bas ini, terus-menerus main mengikuti progressi akor yang mengiringi lagu. Selain dari fungsinya sebagai dasar dari akor lagu, gitar bas elektrik 
juga berfungsi membawakan motif-motif yang biasa dibawakan cello dalam lagu-lagu keroncong. Teknik ini dapat ditemukan dalam lagu Medley Otano Batak \& Minangkabau birama 22/1 - 53/1 dan Bagus Ade birama 2/1 - 14/4 dan birama 18/1 $-24 / 4$.

\section{Saron I dan Saron II}

Berbeda dengan musik campur sari yang berkembang di daerah Jawa, Orkes Keroncong Campur Sari Irama Masa yang terdapat di Kota Sawah lunto ini juga menggunakan alat musik saron. Pono Banue mengatakan bahwa Saron adalah alat musik jenis gambang yang terbuat dari kuningan, besi atau perunggu dengan berbagai variasinya yaitu: demung, saron penerus, peking. Istilah yang dipergunakan di berbagai wilayah Indonesia untuk alat musik ini berbeda-beda (Banue, 1984: 89). Sedangkan M. Soeharto menyatakan bahwa saron adalah alat musik gamelan berupa bilah-bilah logam yang diletakkan di atas wdah kayu berongga yang disebut pangkon. Jumlah bilah-bilah ini sebanyak nada pokok tangga nada antara $6-8$ bilah. Ada beberapa jenis saron: yang berbilah besar dan bernada rendah disebut saron demung, atau kedemung; yang berbilah dan bernada sedang disebut saron barung; dan yang berbilah kecil dan bernada tinggi disebut saron peking atau penerus. Tiap satuan tersebut dimainkan dengan satu pemukul dari kayu, atau kadang-kadang untuk saron peking pemukulnya dari tanduk (Soeharto, 1978: 133-134).

Menurut analisis penulis, Saron I dan Saron II yang dipergunakan oleh Orkes Keroncong Campur Sari Irama Masa adalah saron yang berbilah dan bernada sedang, yang oleh $\mathrm{m}$. Soeharto disebut saron barung. Sebagaimana telah diutarakan di atas, alat musik Saron I dan Saron II yang dipergunakan di dalam Orkes Keroncong Campur Sari Irama Masa dilaras sesuai dengan sistem nada diatonis. Dalam Orkes Keroncong Campur Sari Irama Masa, alat musik Saron I dan Saron II berfungsi ganda. Kadang-kadang alat musik ini berfungsi sebagai pengiring lagu yang berbentuk akor, dan kemudian berfungsi juga sebagai pengiring lagu yang berbentuk arpegio. Ketika alat musik ini memainkan akor, biasanya Saron I memainkan nada yang lebih tinggi daripada nada Saron II. Di dalam akor
Tonika dari tangganada D Mayor misalnya, Saron I memainkan nada a' dan d', dan Saron II memainkan nada d' dan fis'. Nada-nada akor ini dimainkan dalam motif yang sama. Teknik ini dapat dilihat dalam lagu Sawahlunto Kota Idaman birama 2/2 - 54/4 dan 63/1 - 87/2 dan Medley Otano Batak birama 6/1 - 21/4.

Saron I dalam memainkan akor terdapat dalam lagu Sawahlunto Kota Idaman birama 2/2 - 54/4 dan birama 63/1 - 87/2. Selain teknik di atas, Saron I memainkan nada akor pada ketukan lemah (sinkop) sedangkan Saron II memainkan nada akor pada ketukan kuat. Teknik ini dapat dilihat dalam lagu Bagus Ade birama 30/1 - 44/4. Saron I dan Saron II juga memainkan teknik arpegio, namun antara Saron I dan Saron II memainkan nada dengan teknik yang berbeda, di antaranya sebagai berikut (1) Saron I dan Saron II memainkan nada dalam wilayah yang berbeda; (2) Saron I dan Saron II dimainkan dengan teknik permainan rangkap; (3) Saron I memainkan nada 1/16 dan Saron II memainkan nada 1/8. Teknik seperti ini terdapat dalam lagu Sawahlunto Kota Idaman birama 55/1 - 62/4, Medley Otano Batak \& Minangkabau birama 2/1 - 53/4 dan Bagus Ade birama $2 / 1-8 / 4$, birama $9 / 1-14 / 4$; birama $18 / 1$ - 24/4; dan birama 46/1 - 52/4.

\section{Drum (set)}

Pada dasarnya teknik permainan drum dalam kelompok Orkes Keroncong Campur Sari Irama Masa sama dengan teknik permainan drum pada musik pop. Dalam arti kata bahwa drum adalah sebagai pengatur tempo lagu, dan memainkan motif irama sesuai dengan irama lagu yang diiringi.

\section{Gendang Bermuka Dua}

Gendang bermuka dua yang dipergunakan ada 2 buah yang terdiri dari sebuah gendang besar dan sebuah gendang kecil. Kedua buah gendang ini dimainkan oleh satu orang pemain. Kelembutan permainan gendang dalam Orkes Keroncong Campur Sari Irama Masa menjadikan suatu ciri khas dari pembawaan lagu-lagu yang dibawakan. Pada dasarnya alat musik ini juga berfungsi sebagai pengatur tempo, namun pada lagu Bagus Ade, gendang lebih berperan membawakan motifmotif ritme Sunda. 


\section{Keyboard}

Keyboard dalam pertunjukan Orkes Keroncong Campur Sari Irama Masa pada dasarnya hanya berfungsi sebagai akor pengiring atau accompangement.

\section{Vokal}

Dalam hal ini penyanyi Orkes Keroncong Campur Sari Irama Masa pada dasarnya menyanyikan lagu sesuai dengan karakter lagu yang dibawakan. Berbeda dengan musik campur sari di Jawa, yang menuntut seorang vokalis untuk membawakan cengkok atau gregel dari lagu-lagu Jawa yang dibawakan. Informasi-informasi dan analisis di atas amat penting dipergunakan dalam melihat sebuah genre musik daerah. Melalui informasi tersebut akan terlihat perbedaan antara sebuah genre musik yang sama yang berasal dari suatu daerah dengan genre musik yang terdapat di daerah lain.

\section{Pluralitas Musikal dalam Orkes Keroncong Campur Sari Irama Masa Sawahlunto}

Indikator yang paling tampak mengenai refleksi pluralitas masyarakat Sawahlunto dalam orkes keroncong campur sari adalah penggunaan alat musiknya. Dalam pertunjukan orkes keroncong campur sari, akhir-akhir ini selalu menggunakan biola, flute, cak, cuk, gitar, cello, kontra bass, gitar bass elektrik sebagai pengganti kontra bass dan cello, keyboard, seruling Batak, sedangkan alat perkusi yaitu saron 1, saron 2, drum, kendhang besar, kendhang kecil serta tamburin. Biasanya dalam pertunjukan campur sari yang berkembang di Jawa menggunakan alat musik keroncong dicampur dengan alat musik gamelan Jawa. Walaupun alat musik keroncong menggunakan sistem nada diatonis, namun gamelan Jawa di dalam musik campur sari tetap di stem sesuai menurut aturan yang telah ditetapkan sistem nada Jawa, yang menggunakan sistem nada pelog (ji-lu - pat - mo - nem - ji); dan slendro (ji - ro - lu - pat -nem - ji).

Pertunjukan musik campur sari di Sawahlunto ini, selain menggunakan alat musik Barat sebagaimana yang telah disebutkan di atas, juga menggunakan alat musik daerah Jawa seperti saron, yang terbuat dari lempengan tembaga atau baja. Sistem nada yang dipergunakan pada saron dalam gamelan Jawa adalah sistem nada Pelog dan Slendro. Bambang Yudoyono menyatakan bahwa saron berlaras pelog terdiri dari 7 wilahan nada-nada Bem (1), Gulu, (2) Dada, (3) Pelog, (4) Lima, (5), Nem, (6) serta Barang, sedangkan saron berlaras slendro terdiri dari 6 wilayah nada yang terdiri dari: Barang (1) Gulu (2), Dada (3), Lima (5) dan Nem (6) (Yudoyono. 1984: 111). Tetapi untuk memenuhi kebutuhan kelompok musik Orkes Keroncong Campur Sari Irama Masa ini, alat musik tersebut dimodifikasi dan dibuat dalam rakitan berdasarkan tangga nada diatonis. yaitu tangga nada yang mempunyai jarak satu nada dan setengah nada $(1-2-3-4-$ $5-6-7-1 / \mathrm{do}-\mathrm{re}-\mathrm{mi}-\mathrm{fa}-\mathrm{sol}-\mathrm{la}-\mathrm{si}-\mathrm{do})$.

Fungsi saron dalam pertunjukan gamelan Jawa biasanya memainkan melodi pokok, akan tetapi melodi pokok tersebut divariasikan sehingga dimainkan dengan ketukan dua kali lipat lebih cepat dari melodi pokok. Saron penerus dapat mengubah susunan nada dengan cara melipatkan tempo balungan. Teknik permainan seperti itu juga masih ditemukan dalam grup Orkes Keroncong Campur Sari Irama Masa, tetapi sudah dikembangkan dengan teknik lain. Saron yang biasa digunakan sebagai melipatkan tempo pada balungan, pada campur sari ini saron di samping berfungsi sebagai pembawa melodi pada intro, interlude, dan coda, juga berfungsi sebagai pembawa iringan akor yang dimainkan dengan teknik arpegio (akor pecah) maupun akor serempak. Walaupun nada-nada yang dimainkan sudah menggunakan sistem nada-nada diatonis, namun teknik permainan saron pada gamelan, tetap dimainkan, terutama pada saron 2.

Penggunaan teknik-teknik yang berbaur antara teknik pukulan saron gamelan Jawa dengan teknik pukulan saron dengan teknik arpegio (akor pecah) maupun akor serempak (Barat) inilah yang menjadikan grup Orkes Keroncong Campur Sari Irama Masa ini menjadi tidak terikat pada lagu-lagu Jawa semata, namun juga dapat memainkan lagu jenis apapun dan lagu dari daerah manapun. Dengan demikian grup ini tidak hanya membawakan lagu-lagu Jawa saja, namun juga dapat membawakan lagu-lagu pop, bahkan lagu Baratpun bisa dimainkan oleh grup campur sari ini. 
Walaupun saron tidak dilaras menurut Saron yang digunakan di Jawa, namun pada pertunjukannya masih tetap bisa mengiringi lagulagu Jawa, bahkan tidak mengurangi terhadap pertunjukan lagu tersebut. Kendhang pada gamelan Jawa biasanya digunakan untuk mengatur tempo dan membuat tempo yang sesuai dengan lagu, mengendalikan perpindahan satu bagian lagu ke bagian lagu yang lain dan menandai akhir sebuah lagu. Namun pada grup campur sari ini kendhang digandeng dengan drum, yang fungsinya untuk dapat mengimbangi alat musik elektronik lainnya. Dalam pertunjukannya grup campur sari ini lebih cenderung menyesuaikan dengan selera masa kini. Lagu-lagu yang dibawakan di samping membawakan lagu-lagu daerah seperti Jawa, Batak, Minang, Sunda, dan sebagainya, juga tidak ketinggalan lagu-lagu yang "trend" di tengahtengah masyarakat saat ini. Dengan demikian grup campur sari ini merupakan suguhan yang menarik bagi masyarakat mulai dari kalangan bawah sampai kalangan atas.

Tidak seluruh lagu yang ditampilkan menggunakan alat musik yang komplit, untuk lagu Jawa misalnya; seruling Batak tidak digunakan dalam lagu tersebut, namun alat musik saron tetap berfungsi untuk seluruh lagu, baik lagu Jawa, Batak, Minang, Sunda, maupun lagu-lagu pop lainnya. Walaupun komposisi alat musik pendukungnya juga terdiri dari alat musik keroncong, namun tidak selalu lagu dibawakan dengan karakter keroncong. Adakalanya lagu digarap sesuai dengan karakter lagu tersebut, misalnya lagu pada kalimat A dibawakan dengan gaya slow beat, namun pada kalimat B digarap dengan gaya keroncong. Di samping itu juga ditemukan penggarapan lagu yang dilakukan dengan cara medley atau penggabungan dua atau beberapa buah lagu yang berasal dari daerah berlainan. Misalnya lagu Otano Batak yang berasal dari Sumatera Utara, digabungkan dengan lagu Minangkabau yang berasal dari Minangkabau. Penggabungan lagu tersebut bukan berarti habis lagu satu disambung lagu kedua, namun cara penyajiannya dicampur aduk. Habis kalimat A lagu Otano Batak, disambung dengan kalimat B lagu Minangkabau, atau sebaliknya. Untuk lebih jelasnya dapat dilihat partitur lagu Otano Batak yang dalam pertunjukannya di-medley-kan dengan lagu Minangkabau. Dari pertunjukan yang demikian dapat menggambarkan keberagaman etnis masyarakat kota Sawahlunto. Walaupun berasal dari etnis yang berbeda namun dapat disatukan dalam kehidupan yang damai. Dalam seni pertunjukan menyatukan satu budaya dengan budaya lainnya yang berbeda merupakan daya tarik tersendiri dari sebuah pertunjukan Orkes Keroncong Campur Sari Irama Masa.

Dari pertunjukan terakhir kelompok campur sari yang diberi nama Orkes Keroncong Campur Sari Irama Masa di Pentas Pedati V Bukittinggi, dapat dilihat bahwa penampilan kelompok ini amat menarik perhatian penonton. Ketertarikan penonton di antaranya adalah, gabungan berbagai macam jenis alat musik yang pada saat itu terdiri dari saron 1, saron 2, kendhang kecil dan besar, seruling Batak, gitar bas, gitar melodi, cuk, keyboard, dan drum. Dalam penampilan tersebut jelas terlihat perpaduan berbagai macam suku bangsa, misalnya dari para pemain yang terdiri dari suku Jawa, Minang, Batak, Sunda, Nias, dan sebagainya. Sedangkan lagu-lagu yang dibawakan juga berasal dari berbagai macam suku bangsa tersebut, termasuk lagu Jawa, Minang, Batak, Sunda, Barat, Pop Indonesia, Dangdut, Melayu, Keroncong, dan sebagainya.

Fenomena inilah yang menarik karena menggambarkan kondisi pluralitas masyarakat Sawahlunto yang majemuk. Penyerapan berbagai unsur di dalam lagu-lagu yang berasal dari berbagai etnis tersebut berpadu sehingga menjadi sebuah budaya baru, yaitu budaya masyarakat Sawahlunto. Dalam hal ini memperlihatkan bahwa para pemain Orkes Keroncong Campur Sari Irama Masa telah melakukan proses kreativitas. Proses kreativitas tersebut dapat dilihat dalam lagu-lagu yang menjadi bagian dari setiap pertunjukan mereka.

\section{Orkes Keroncong Campur Sari sebagai Representasi Pluralitas Masyarakat}

Orkes Keroncong Campur Sari Irama Masa merupakan fenomena budaya yang unik. Keberadaannya disangga oleh berbagai instru men musik yang berasal dari berbagai etnis masyarakatnya, baik yang diatonis maupun yang pentatonis. Sementara itu, musik etnis yang pentatonis pun memiliki berbagai karakter masingmasing. Penyatuan berbagai karakter dalam sebuah satu kesatuan "karakter baru" itupun bukanlah 
pekerjaan yang mudah. Oleh karena itu fenomena yang terjadi dalam Orkes Keroncong Campur Sari Irama Masa menunjukkan adanya upaya masyarakat Sawahlunto membangun budaya yang berasal dari multietnis masyarakatnya. Tentunya usaha ini tidak akan muncul apabila tidak dilandasi kesadaran pribadi sebagai anggota sebuah masyarakat yang plural. Sikap demikian bukan berarti muncul begitu saja, tetapi pada dasarnya sangat diwarnai sejarah sosial dari masyarakat Sawahlunto itu sendiri.

Sebagaimana diketahui bahwa masyarakat Sawahlunto, selain masyarakat asli yang sebelumnya tinggal di sana, pada Jaman penjajahan Belanda di datangkan orang-orang dari berbagai daerah untuk bekerja sebagai buruh tambang. Setelah Indonesia merdeka, mereka tidak kembali ke daerah asalnya, tetapi tetap tinggal dan menjadi penduduk Sawahlunto. Dalam kurun waktu yang relatif panjang, tentunya masing-masing etnis secara intensif menjalin dialektika budaya yang akibatnya adanya sikap saling memahami dan menghormati.

Pada sisi lain, karena mereka sudah merasa bertumpah darah Sawahlunto, pola pikir mereka tidak lagi didominasi oleh budaya etnis asal mereka, tetapi secara perlahan telah terbentuk pola etnis yang baru, yaitu Sawahlunto. Atas kesadaran itulah kemudian muncul upayaupaya rekonstruksi budaya sebagai representasi situasi dan kondisi masyarakat Sawahlunto yang multietnis. Meskipun musik gamelan Jawa, music Batak, music keroncong, dan berbagai musik etnis lainnya memiliki karakter yang berbeda, tetapi setelah dikerjakan oleh masyarakat multi etnis yang telah menyatu pola pikirnya, akhirnya membentuk kebudayaan baru yang multietnis tetapi satu rasa, yang salah satunya adalah Keroncong Campur Sari Irama Masa

\section{Penutup}

Berdasarkan uraian di atas dapat ditarik kesimpulan bahwa musik Keroncong Campur Sari yang hidup di dalam masyarakat Sawahlunto sangat berbeda dengan yang hidup di Jawa. Alat musik yang digunakan di sini dapat dikatakan mengambil atau mengakomodasi alat musik dari berbagai etnis yang dikatakan hampir mewakili semua etnis masyarakat yang hidup di Sawahlunto, dan bahkan diberi penambahan dengan alat musik
Barat. Kondisi demikian pula yang menjadi alasan bahwa kesenian tersebut tidak bernama Campur Sari seperti di Jawa, tetapi telah menjadi Orkes Keroncong Campur Sari. Meskipun masih menggunakan istilah campur sari, tetapi pola permainan musiknya dan repertoar lagunya pun merupakan percampuran dari berbagai tradisi masyarakat yang hidup di dalamnya. Dengan demikian jelas bahwa pluralisme masyarakat Sawahlunto di sini terrefleksikan pada pluralisme alat musik dan permainan orkesnya.

Bukan hanya persoalan tersebut, dalam hal nafas lagu dan liriknya pun juga merupakan percampuran dari berbagai etnik masyarakat yang hidup di dalamnya. Dengan demikian jelas bahwa pluralisme yang berada dalam Orkes Keroncong Campur Sari merupakan pluralisme total sehingga mampu mewakili pluralisme masyarakatnya. Artinya bahwa, meskipun namanya menggunakan Campur Sari yang merupakan etnik Jawa, tetapi di dalamnya telah mewadahi ruh musik masing-masing etnik. Artinya bahwa di Sawhlunto telah terbangun budaya baru sebagai hasil akulturasi multi etnik dalam masyarakat urban. Fenomena demikian kiranya dapat dijadikan contoh oleh masyarakat lain yang memiliki multi etnik, khususnya dalam masyarakat urban.

Munculnya Orkes Keroncong Campur Sari sebagai genre musik baru ini merupakan kolaborasi yang dahsyat yang dilakukan oleh masyarakat seni di Sawahlunto. Dengan kesadaran individual mereka yang pada akhirnya membangun kesadaran kolektif, mampu membangun sebuah kebudayaan baru. Fenomena budaya di Sawahlunto ini tampaknya bukanlah satusatunya yang terjadi di Indonesia, atau bahkan dibelahan bumi ini. Artinya bahwa rekonstruksi dan konstruksi budaya sangat terbuka terjadi di mana-mana.

\section{Kepustakaan}

Bambang Yudoyono. 1984. Gamelan Jawa awal-mula, makna masa depanya. PT. Karya UNIPRESS 1984. IKAPI. Jakarta.

Bangun, Jabatin. 1994. "Perilaku Sosial dan Gaya penyajian Repertoar Guro-guro Aron pada Masyarakat Karo". Skripsi. Jurusan Etnomusikologi Universitas Sumatera Utara, Medan. 
Harmunah. 2005. Musik Keroncong: Sejarah, Gaya, dan Perkembangan. Yogyakarta: Pusat Musik Liturgi.

Iswandi, Dedy. 2003. "Eksistensi Musik Keroncong Campur Sari di Kelurahan Durian II Kecamatan Barangin Kodya Sawahlunto." Skripsi Jurusan Musik Sekolah Tinggi Seni Indonesia Padangpanjang.

Laksono, Joko Tri. 2010. "Campur Sari Gunung Kidul Maju Lancar: Awal Mula Keberadaannya. Tesis S-2 Program Studi Pengkajian Seni Pertunjukan. Program Pasca Sarjana. Universitas Gadjah Mada Yogyakarta.

Judith Becker. 1980. The Traditional Music In Modern Jawa. Honolulu: The University of Hawai.

Latifah Kodijat. 1986. Istilah-Istilah Musik. Jakarta: Djambatan.

Ali, Lukman. 1994. Kamus Besar Bahasa Indonesia. Jakarta: Balai Pustaka.
M. Soeharto. 1978. Kamus Musik Indonesia. Jakarta: PT. Gramedia.

Banue, Pono. 1984. Pengantar Pengetahun Alat Musik. Jakarta: CV Baru.

Soedarso, Sp. 1990. Tinjauan Seni. Yogyakarta: Saku Dayar Sana.

\section{Informan}

Adjoem (70 tahun), Seniman musik keroncong di Sawahlunto.

Kuncung (66 tahun) Seniman keroncong di Sawahlunto.

Tarmin (67 tahun), Pemain biola dan seniman musik keroncong keturunan Jawa.

Wakidjan (56 tahun), Seniman musik di Sawahlunto. 